\title{
Studi Formulasi, Sifat Fisiko Kimia, Stabilitas Dan Tingkat Kesukaan Konsumen Terhadap Minyak Aromaterapi Sereh Wangi
}

\author{
Study Of Formulation, Physico Chemical Characteristics, Stability And Consumer \\ Pleasure Level On Citronella Aromatherapy Oil
}

\author{
Shintawati dan Zulfahmi \\ Politeknik Negeri Lampung, Jl. Soekarno Hatta No 10 Bandar Lampung, 35215, Indonesia \\ e-mail: shintawati@polinela.ac.id
}

\begin{abstract}
Abstrak
Sereh sejak dahulu telah digunakan sebagai bahan obat luar. Minyak atsiri sereh wangi, dikenal dengan nama citronella, secara komersil diperoleh dari distilasi uap daun tanaman sereh wangi. Penelitian ini bertujuan untuk mempelajari formulasi, sifat fisiko kimia, stabilitas dan tingkat kesukaan konsumen terhadap dua formula produk minyak aromaterapi sereh wangi. Formula pada penelitian ini merupakan pengembangan dari formula produk sediaan cair yang dikembangkan oleh peneliti sebelumnya. Produk minyak aromaterapi sereh wangi dibuat dalam 2 formula yaitu formula J2 dan J3 yang terdiri minyak kelapa, minyak gandapura, kristal mentol, minyak piperin, minyak lemon dan minyak sereh wangi dengan perbandingan 1:5:6:2:2:4 dan 1:5:6:2:0:6. Metode pembuatan minyak aromaterapi diawali dengan pemanasan campuran kristal mentol, minyak kelapa dan minyak gandapura pada suhu 60-70 ${ }^{\circ} \mathrm{C}$. Setelah campuran mencapai suhu kamar ditambahkan minyak atsiri lainnya. Parameter fisiko kimia produk yang diuji antara lain viskositas, densitas dan $\mathrm{pH}$. Evaluasi formulasi minyak aromaterapi dilaksanakan melalui uji iritasi terhadap 10 panelis, uji angka lempeng total serta uji stabilitas selama 30 hari pada suhu kamar, $30 \pm 2^{\circ} \mathrm{C}$ dan $40 \pm 2^{\circ} \mathrm{C}$ dan dilaksanakan dengan 3 kali ulangan. Uji tingkat kesukaan konsumen dilaksanakan oleh 26 orang panelis tidak terlatih dengan atribut sensori meliputi warna, wangi alami, kesegaran, kehangatan, tekstur dan kesukaan keseluruhan terhadap produk. Hasil penelitian menunjukkan formula J2 dan formula J3 memiliki pH masing-masing 5,25 dan 5,47 yang aman bagi kulit. Uji iritasi menunjukkan kedua formula J2 dan J3 tidak menimbulkan iritasi pada kulit. Hasil uji stabilitas menunjukkan kedua formula stabil pada ketiga variasi suhu dimana tidak ada perubahan pH, warna maupun wangi alami selama penyimpanan 30 hari. Formula J2 dan J3 memenuhi kriteria Peraturan Kepala BPOM Nomor 12 tahun 2014 tentang Persyaratan Obat Tradisional, dimana kandungan angka lempeng total formula J2 dan J3 masing-masing 1,1 × $10^{4} \mathrm{koloni} / \mathrm{ml}$ dan $0 \mathrm{koloni} / \mathrm{ml}$. Analisa Anova menunjukkan terdapat beda nyata antara formula J2 dan J3. Evaluasi sensori memperlihatkan panelis lebih menyukai formula dengan penambahan minyak lemon, J2 dibandingkan dengan formula tanpa penambahan minyak lemon, J3. Nilai rata-rata kesukaan panelis secara keseluruhan terhadap formula J2 dan J3 masing-masing 4,23 dan 2,69.
\end{abstract}

Kata kunci : formula, konsumen dan sereh wangi.

\begin{abstract}
Cymbophogon had been used as traditional medicine.Citronella oil commercially obtained from the steam distillation of Combophogon leaves. This research aims to study the formulation, physicochemical properties, stability and to know costumer preference of aromatic citronella aromatherapy medicated oil formula. Citronella aromatherapy medicated oil are made in 2 formulas namely J2 and J3 formulas consisting of coconut oil, gandapura oil, menthol crystals, piperin oil, lemon oil and citronella oil with a ratio of 1: 5: 6: 2: 2: 4 and 1: 5: 6: 2: 0: 6. The method of making aromatherapy oils begins with heating a mixture of menthol crystals, coconut oil and gandapura oil at a temperature of $60-70^{\circ} \mathrm{C}$. After the mixture reaches room temperature, other essential oils are added. Physicochemical parameters of the product being tested include viscosity, density and $\mathrm{pH}$. Evaluation of aromatherapy oil formulations was carried out through irritation tests on 10 panelists, total plate count test and stability test for 30 days at room temperature, $30 \pm 2^{\circ} \mathrm{C}$ and $40 \pm 2^{\circ} \mathrm{C}$ and carried out with 3 replications. The consumer preference level test was carried out by 26 untrained panelists with sensory attributes including color, natural fragrance, freshness, warmth, texture and overall liking for the product. The results showed that formula J2 and formula J3 had pH of 5.25 and 5.47 which were safe for the skin. The irritation test shows that the two formulas J2 and J3 do not cause skin irritation. The results of the stability test showed that the two formulas were stable at all three variations in temperature where there was no change in $\mathrm{pH}$, color or natural fragrance during 30 days storage. Formulas
\end{abstract}


J2 and J3 meet the criteria of the Head of BPOM Regulation No. 12 of 2014 concerning Requirements for Traditional Medicines, where the total plate content of formulas J2 and J3 are $1.1 \times 10^{4}$ colonies $/ \mathrm{ml}$ and 0 colonies / ml, respectively. Anova analysis shows that there are significant differences between formulas J2 and J3. Sensory evaluation showed that panelists preferred formula with the addition of lemon oil, J2 compared to formula without the addition of lemon oil, J3. The overall average value of panelists' preferences for formulas J2 and J3 were 4.23 and 2.69, respectively.

Keywords: formula, consumer and citronella.

\section{Pendahuluan}

Minyak sereh wangi dengan nama dagang citronella merupakan komoditi minyak atsiri dengan permintaan yang tinggi, dimana kebutuhan minyak sereh wangi dunia baru terpenuhi 50-60\% (Serumpun Asa, 2018). Indonesia merupakan negara penghasil minyak sereh wangi terbesar kedua di dunia setelah China. Hampir 75\% ekspor minyak sereh wangi dalam bentuk minyak atsiri kasar (Kementerian Perdagangan, 2011). Tanaman sereh wangi memiliki umur panen yang relatif singka dan pemeliharaannya tidak rumit (Setiawan, 2018). Minyak sereh wangi secara komersial diperoleh dari distilasi daun tanaman sereh wangi dengan kandungan minyak berkisar 0,01-10\% (Vivek Chauhan, 2016). Minyak sereh wangi telah banyak diaplikasikan di industri sabun, parfum, kosmetik, aroma dan repelant nyamuk (R.V. Gheetha, 2014).

Penelitian pengembangan produk minyak sereh wangi telah banyak dilakukan, Dwi Setyaningsih, 2010 mengaplikasikan minyak sereh wangi dan geraniol dalam pembuatan skin lotion. Muhtaridi, 2010 mengkaji produk roll on berbasis minyak sereh wangi yang ditambahkan berbagai bahan kimia. Adenian, 2012, mengembangkan formulasi cream anti nyamuk dan Wa Ode 2016, mengkaji produk lotion repelan nyamuk dari campuran minyak atsiri sereh wangi dan nilam.

Uji kesukaan konsumen terhadap suatu produk dapat menjadi salah satu indikator produk tersebut dapat diterima oleh masyarakat. Citronelal merupakan salah satu zat aktif dalam minyak sereh wangi yang memberikan kontribusi aroma lemon (WT Eden, 2018). Penambahan minyak lemon pada produk berbahan dasar minyak sereh wangi diduga akan meningkatkan kesukaan konsumen terhadap produk tersebut. Pengembangan formulasi produk minyak aromaterapi dari minyak sereh wangi yang diperkaya minyak lemon dan disukai konsumen belum pernah dilakukan. Penelitian ini bertujuan untuk mempelajari formulasi, sifat fisiko kimia, stabilitas dan kesukaan konsumen terhadap dua formula produk minyak aromaterapi sereh wangi.

\section{Metode Penelitian}

Bahan yang digunakan dalam penelitian ini antara lain minyak sereh wangi hasil distilasi oleh Kelompok Tani Hutan Agro Sumber Rejeki Kabupaten Lampung Selatan, minyak atsiri lemon, minyak peppermint, minyak gandapura, minyak kelapa atau minyak putih yang berasal dari Politeknik Negeri Lampung dan menthol kristal. Alat yang digunakan antara lain gelas ukur, penangas, timbangan elektronik, gelas kimia, botol sampel, $\mathrm{pH}$ meter, panci, termometer, inkubator, viscometer, pikonometer, stopwatch dan corong.

Penelitian dilaksanakan pada bulan April 2019 hingga Oktober 2019. Penelitian ini menggunakan jenis penelitian eksperimen di Laboratorium Analisis Kimia Politeknik Negeri Lampung. Pengujian viskositas dilaksanakan di Laboratorium Teknologi Hasil Pertanian Politeknik Negeri Lampung. Pengujian mikrobiologi angka lempeng total dilakukan di Laboratorium Balai Riset dan Standarisasi Industri Bandar Lampung. Uji stabilitas dilaksanakan di Laboratorium UPTD Balai Pengujian dan Sertifikasi Mutu Barang Dinas Perdagangan Provinsi Lampung.

Penelitian ini dilakukan dengan membandingkan formula minyak angin aroma terapi dengan (J2) dan tanpa penambahan minyak lemon (J3). Perbandingan minyak kelapa, minyak gandapura, kristal mentol, minyak piperin, minyak lemon dan minyak sereh wangi pada masing masing formula adalah formula $\mathrm{J} 2=1: 5: 6: 2: 2: 4$ dan formula $\mathrm{J} 3$ $=1: 5: 6: 2: 0: 6$.

\section{Pembuatan Minyak Aromaterapi}

Prosedur pembuatan minyak aromaterapi adalah menimbang minyak kelapa, gandapura dan mentol kristal sesuai formula, memanaskan bahan tersebut pada suhu $60-70^{\circ} \mathrm{C}$ hingga campuran mencair dan homogen. Campuran didiamkan hingga mencapai suhu kamar lalu ditambahkan minyak sereh, minyak lemon, dan minyak peppermint kemudian diaduk hingga campuran homogen. 


\section{Analisis Fisiko Kimia Produk}

Analisa sifat fisiko kimia produk meliputi densitas, viskositas menggunakan viskometer Oswald, pengujian pH menggunakan $\mathrm{pH}$ digital serta analisa sensori dengan atribut sensori wangi alami dan warna.

\section{Uji Iritasi dan Uji Stabilitas}

Uji iritasi produk dilakukan pada 10 orang panelis dengan metode Klingman, dengan mengoleskan produk pada lengan dan ditutup plaster, setelah 5 jam, warna kemerahan mengindikasikan adanya iritasi. Evaluasi stabilitas dilakukan pada suhu kamar, $30^{\circ} \mathrm{C}$ dan $40^{\circ} \mathrm{C}$ selama 1 bulan, dilakukan sebanyak 3 kali ulangan dengan parameter uji $\mathrm{pH}$ dan atribut evaluasi sensori warna dan wangi alami.

\section{Uji Mikrobiologi dan Uji Kesukaan Konsumen}

Sampel uji dari pengujian stabilitas, diuji secara mikrobiologis menggunakan uji angka lempeng total. Sedangakan uji kesukaan konsumen dilakukan dengan pengujian sensori pada 26 orang panelis tidak terlatih. Uji sensori dilakukan dengan penilaian menggunakan skala Hedonik 1-5 dan dianalisis menggunakan Anova. Skala 5 menyatakan sangat suka terhadap produk, skala 4 menyatakan suka, skala 3 menyatakan biasa saja, skala 2 menyatakan kurang suka dan skala 1 menyatakan tidak suka.

\section{Hasil Dan Pembahasan}

Produk minyak aromaterapi sereh wangi yang dikaji dibuat dalam 2 formula yaitu formula J2 dengan penambahan minyak lemon dan formula J3 tanpa penambahan minyak lemon.

\section{Sifat Kimia- Fisik Produk}

Sifat kimia-fisik produk minyak angin aromaterapi citronella disajikan pada Tabel 1.

Tabel 1. Hasil Uji SifatFisik - Kimia Produk Minyak Angin Aroma terapi Citronella

\begin{tabular}{cccc}
\hline Formula & $\mathrm{pH}$ & Densitas $(\mathrm{g} / \mathrm{ml})$ & $\begin{array}{c}\text { Viscositas } \\
\text { (cp) }\end{array}$ \\
\hline $\mathrm{J} 2$ & 5,25 & 1,03 & 1.1675 \\
$\mathrm{~J} 3$ & 5,47 & 1,04 & 1.2671 \\
\hline
\end{tabular}

Tabel 1 memperlihatkan derajat keasamaan untuk formula J2 dan J3 masing-masing adalah 5,25 dan 5,47, kedua nilai $\mathrm{pH}$ tersebut masih berada dalam rentang aman bagi kulit. Menurut Raditya, 2017, nilai derajat keasaman produk kosmetik yang aman bagi kulit adalah 4,5-6,5. Densitas formula J2 maupun J3 lebih dari $1 \mathrm{~g} / \mathrm{ml}$ hal ini diduga karena penggunaan kristal mentol yang berbentuk padat. Formula J2 dan J3 memiliki viskositas masing-masing 1,1675 dan 1,2671 cP. Gliserin 85\% dalam air memiliki viskositas $5800 \mathrm{cP}$ dan dikategorikan fluida Newtonian (Raditya, 2017). Nilai viskositas kesuluruhan formula lebih kecil dari nilai viskositas gliserin $85 \%$ sehingga keseluruhan formula merupakan fluida Newtonian. Fluida yang mengikuti sifat alir cairan Newtonian memiliki keunggulan yaitu memberikan profil terbaik dikarenakan mudah dikeluarkan dari tempat penyimpanan dan nilai viskositasnya cenderung konstan (Raditya, 2017). Sutiah, 2008 mengemukakan viskositas dan densitas minyak dapat dijadikan parameter penentu keaslian produk minyak.

Sifat organoleptik formula J2 dan J3 untuk ulangan 1, 2 dan 3 disajikan Tabel 2. Formula J2 merupakan formula dengan penambahan minyak lemon sedangkan formula J3 merupakan formula tanpa penambahan minyak lemon. Hasil pengamatan memperlihatkan formula J2 memberikan warna kuning yang lebih terang dibandingkan formula J3, hal ini dikarenakan minyak lemon memiliki warna kuning terang sedangkan minyak sereh wangi memiliki warna kuning pucat. Penilaian wangi alami berdasarkan wangi sereh yang dihasilkan, semakin kuat wangi sereh maka semakin kuat wangi alami yang dihasilkan. Hasil pengamatan organoleptis menunjukkan formula J3 memiliki wangi alami yang kuat dibandingkan J2.

\section{Uji Stabilitas Produk}

Uji stabilitas dilaksanakan dengan penyimpanan produk pada suhu kamar, $30 \pm 2^{\circ} \mathrm{C}$ dan $40 \pm 2{ }^{\circ} \mathrm{C}$ masing-masing selama 1 bulan dan dilakukan dengan 3 kali ulangan. Uji stabilitas dilaksanakan dengan menguji $\mathrm{pH}$ dan atribut sensori warna dan wangi alami setiap minggu. 
Tabel 2. Hasil Uji Organoleptik Produk Minyak Angin Aromaterapi Citronella

\begin{tabular}{|c|c|c|c|c|c|c|c|}
\hline \multirow{2}{*}{$\begin{array}{c}\text { Kode } \\
\text { Produk }\end{array}$} & \multirow{2}{*}{$\begin{array}{c}\text { Minggu } \\
\mathrm{Ke}-\end{array}$} & \multicolumn{3}{|c|}{ WARNA KUNING } & \multicolumn{3}{|c|}{ WANGI ALAMI } \\
\hline & & Ulangan ke-1 & Ulangan ke-2 & $\begin{array}{c}\text { Ulangan ke- } \\
3\end{array}$ & $\begin{array}{c}\text { Ulangan ke- } \\
1\end{array}$ & $\begin{array}{c}\text { Ulangan } \\
\text { ke-2 }\end{array}$ & $\begin{array}{l}\text { Ulangan } \\
\text { ke-3 }\end{array}$ \\
\hline \multirow[t]{4}{*}{$\mathrm{J} 2$} & 1 & ++++ & ++++ & ++++ & ++++ & ++++ & ++++ \\
\hline & 2 & ++++ & ++++ & ++++ & ++++ & ++++ & ++++ \\
\hline & 3 & ++++ & ++++ & ++++ & ++++ & ++++ & ++++ \\
\hline & 4 & ++++ & ++++ & ++++ & ++++ & ++++ & ++++ \\
\hline \multirow[t]{4}{*}{$\mathrm{J} 3$} & 1 & +++ & +++ & +++ & +++++ & +++++ & +++++ \\
\hline & 2 & +++ & +++ & +++ & +++++ & +++++ & +++++ \\
\hline & 3 & +++ & +++ & +++ & +++++ & +++++ & +++++ \\
\hline & 4 & +++ & +++ & +++ & +++++ & +++++ & +++++ \\
\hline
\end{tabular}

Keterangan : Semakin banyak tanda + menunjukkan semakin kuat warna kuning atau semakin kuat wangi alami

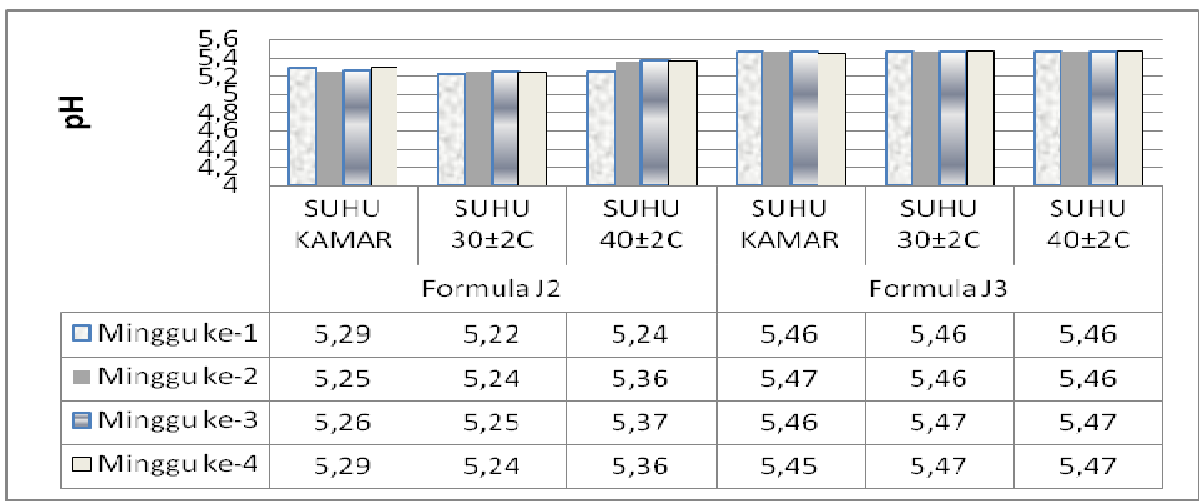

Gambar 1. Hasil Uji Stabilitas Formula J2 dan J3

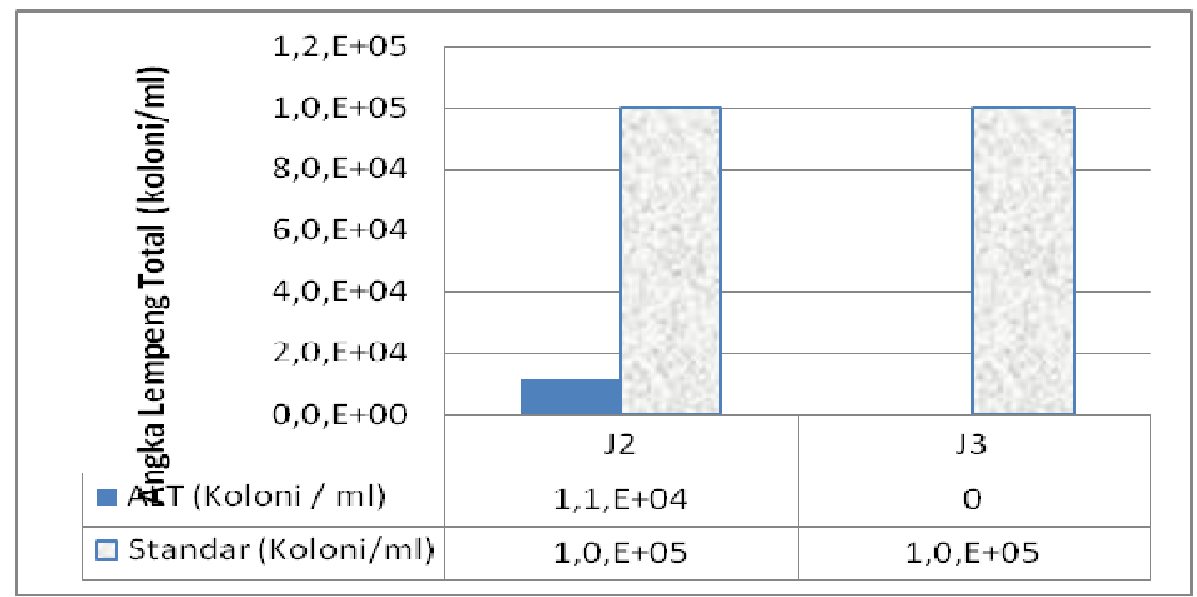

Gambar 2. Hasil Uji ALT Pada Formula J2 dan J3

Tabel 3. Hasil Analisis Sidik Ragam Formula J2 dan J3 Dengan Selang Kepercayaan 95\%

\begin{tabular}{lcccccc}
\hline & \multicolumn{5}{c}{ Atribut Sensori } \\
\cline { 2 - 7 } & Warna & Wangi Alami & Kesegaran & Kehangatan & Tekstur & $\begin{array}{c}\text { Kesukaan Terhadap } \\
\text { Keseluruhan Produk }\end{array}$ \\
\hline Nilai F Hitung & 32 & 41,76 & 15,15 & 8,17 & 49,95 & 42,92 \\
Nilai F Tabel & 3,38 & 3,38 & 3,38 & 3,38 & 3,38 & 3,38 \\
Nilai rata-rata J2 & 3,65 & 4,54 & 4,31 & 4,58 & 4,35 & 4,23 \\
Nilai rata-rata J3 & 4,69 & 3,23 & 3,54 & 4,08 & 3,15 & $2,693_{30}$ \\
\hline
\end{tabular}


Hasil uji stabilitas produk menunjukkan kedua formula J2 dan J3 stabil pada suhu kamar, $30 \pm 2^{\circ} \mathrm{C}$ dan $40 \pm 2^{\circ} \mathrm{C}$, dimana tidak terjadi perubahan signifikan pada $\mathrm{pH}$ setelah penyimpanan 1 bulan pada berbagai suhu penyimpanan sebagaimana Gambar 1. Tidak adanya perubahan $\mathrm{pH}$ menunjukkan tidak adanya interaksi antar molekul yang ada di dalam produk. Hal yang sama untuk atribut sensori warna dan wangi alami, tidak terjadi perubahan selama penyimpanan.

\section{Uji Iritasi}

Hasil uji iritasi menunjukkan kedua formula J2 dan J3 tidak menimbulkan iritasi pada kulit 10 orang panelis, disimpulkan kedua formula aman bagi kulit.

\section{Uji Mirobiologi}

Uji mikrobiologi dilaksanakan untuk memenuhi Peraturan Kepala BPOM Nomor 12 tahun 2014 tentang Persyaratan Mutu Obat Tradisional.

Hasil uji mikrobiologi memperlihatkan angka lempeng total kedua formula J2 dan J3 masing-masing $1,1 \times 10^{4}$ koloni/ml dan 0 koloni/ml. Berdasarkan Peraturan Kepala BPOM Nomor 12 tahun 2014 tentang Persyaratan Mutu Obat Tradisional, nilai maksimum angka lempeng total adalah $10^{5} \mathrm{koloni} / \mathrm{ml}$, maka kedua formula J2 dan J3 memenuhi persyaratan mutu obat tradisional.

\section{Tingkat Kesukaan Konsumen}

Penilaian terhadap kesukaan terhadap keseluruhan produk, panelis diminta untuk menilai kesukaan produk secara keseluruhan, baik warna, kemasan, wangi alami dan parameter lainnya yang dapat memberikan kesan terhadap suatu produk (Dwi Setyaningsih, 2010). Pengukuran tingkat kesukaan konsumen terhadap produk dilaksanakan dengan uji sensori dengan atribut warna, wangi alami, kesegaran, kehangatan, tekstur dan kesukaan terhadap keseluruhan terhadap produk. Meilgaard, 2007 menyatakan bahwa evaluasi sensori juga dapat menjadi salah satu parameter kepuasan konsumen terhadap suatu produk. Pada penelitian ini panelis diminta untuk menilai masing-masing atribut sensori dengan skala hedonik 1 sampai 5 , yaitu 5 = sangat suka, 4 =suka, 3= biasa saja, sensori 2 = tidak suka dan 1 = sangat tidak suka.

Hasil analisis sidik ragam dengan selang kepercayaan 95\%, sebagaimana Tabel 3, menunjukkan bahwa untuk seluruh atribut sensori perlakuan J2 berbeda nyata dari J3, dimana nilai $\mathrm{F}$ hitung untuk keseluruhan atribut sensori yang berkisar 8,17-49,9, lebih besar dari nilai $F$ tabel yaitu 3,38. Hal ini bermakna penambahan minyak lemon pada formula J2 memberikan perbedaan nyata pada warna, wangi alami, kesegaran, kehangatan, kesukaan terhadap keseluruhan produk dan tekstur dengan formula J3 yang tidak mengandung minyak lemon.

\section{Warna}

Nilai rata-rata kesukaan panelis terhadap warna formula J2 dari J3 masing-masing yaitu 3,65 dan n 4,69. Nilai kesukaan panelis terhadap warna J3 lebih tinggi dari J2 dikarenakan warna J2 lebih kuning dibandingkan J3. Formula J2 mengandung minyak lemon yang berwarna kuning pekat sedangkan formula J3 tidak mengandung minyak lemon. Formula J3 mengandung minyak sereh wangi yang berwarna kuning pucat. Rusmini, 2019 menyatakan bahwa warna adalah salah satu daya tarik utama dan memberikan kesan pertama terhadap penerimaan suatu produk sebelum konsumen mengenali atribut sensori lainnya.

\section{Wangi alami}

Nilai rata-rata atribut sensori wangi alami J2 lebih tinggi dari J3, masing-masing yaitu 4,54 dan 3,23 . Nilai kesukaan panelis terhadap wangi alami J2 lebih tinggi dari J3 menunjukkan panelis menyukai produk yang diberi tambahan minyak lemon. Diduga penambahan minyak lemon memperkuat wangi lemon yang dihasilkan oleh zat aktif citronelal yang terdapat dalam minyak sereh wangi (W T Eden, 2018).

\section{Kesegaran}

Nilai rata-rata atribut sensori kesegaran J2 dan J3 masing-masing adalah 4,31 dan 3,54. Kontribusi kesegaran produk berasal dari penambahan kristal mentol dan minyak atsiri. Kristal mentol memberikan efek dingin dan segar di kulit. Minyak atsiri yang ditambahkan antara lain minyak sereh wangi, minyak pipermin dan minyak lemon. Pada penelitian ini komposisi kristal mentol dan minyak pipermin dibuat konstan, sehingga kontribusi kesegaran produk diduga hanya berasal dari penambahan minyak lemon.

\section{Kehangatan}

Nilai rata-rata atribut sensori kehangatan formula J2 lebih tinggi dari J3, masing-masing yaitu 4,58 dan 4,08. Kontribusi kehangatan 
produk berasal dari penambahan minyak gandapura, minyak pipermin dan minyak sereh wangi. Pada penelitian ini komposisi minyak gandapura dan minyak pipermin dibuat konstan, sehingga diduga kontribusi kehangatan produk berasal dari minyak sereh wangi.

\section{Tekstur}

Nilai rata-rata atribut sensori tekstur J2 lebih tinggi dari J3, masing-masing yaitu 4,35 dan 3,15. Tekstur produk dinilai berdasarkan tingkat kelembutan produk ketika dioleskan di kulit. Salah satu yang mempengaruhi tekstur produk adalah nilai viskositas. Parameter viskositas menyatakan kekentalan suatu fluida cair. Nilai viskositas yang tinggi menunjukkan fluida tersebut lebih kental dibandingkan dengan fluida dengan viskositas yang lebih rendah. Tabel 1 memperlihatkan produk J2 memiliki viskositas yang lebih rendah dari J3 dengan nilai masing-masing viskositas 1,1675 cP dan 1,2671 cP. Disimpulkan panelis lebih menyukai produk dengan tingkat kekentalan yang lebih rendah.

\section{Kesukaan Terhadap Keseluruhan Produk}

Berdasarkan data penilaian kesukaan terhadap keseluruhan produk dilakukan analisis sidik ragam terhadap kedua formula J2 dan J3, didapat bahwa perlakuan J2 berbeda nyata dari J3 dengan nilai F hitung 42,92, lebih besar dari nilai $\mathrm{F}$ tabel yaitu 3,38 . Formula J2 memiliki nilai rata-rata 4,23 dan formula J3 memiliki nilai 2 ,69. Semakin besar nilai menunjukkan semakin tinggi tingkat kesukaan panelis terhadap produk, disimpulkan berdasarkan penilaian panelis terhadap keseluruhan produk, panelis lebih menyukai produk dengan penambahan minyak lemon (formula J2) dibandingkan dengan produk tanpa penambahan minyak lemon (formula J3).

\section{Kesimpulan}

Produk dengan formula J2 dan J3 bersifat stabil, aman bagi kulit serta memenuhi Peraturan Kepala BPOM Nomor 12 tahun 2014 tentang Persyaratan Mutu Obat Tradisional dengan derajat keasaman dan nilai ALT masingmasing produk adalah 5,25 dan 5,47 serta $1,1 \times 10^{4} \mathrm{koloni} / \mathrm{ml}$ dan $0 \mathrm{koloni} / \mathrm{ml}$. Produk dengan formula J2 dan J3 merupakan fluida Newtonian dengan nilai viskositas 1,1675 dan $1,2671 \mathrm{cP}$ dan nilai densitas masing-masing produk J2 dan J3 adalah 1,03 g/ml dan 1,04 $\mathrm{g} / \mathrm{ml}$. Perlakuan terhadap J2 berbeda nyata dari J3 baik untuk atribut sensori warna, wangi alami, kesegaran, kehangatan, tekstur dan kesukaan terhadap keseluruhan produk. Nilai rata-rata kesukaan secara keseluruhan terhadap produk J2 dan J3 masing-masing adalah 4,23 dan 2,69.

\section{Ucapan Terima Kasih}

Terimakasih diucapkan kepada Lembaga Penelitian dan Pengabdian Masyarakat Politeknik Negeri Lampung yang telah mendanai penelitian ini melalui dana DIPA Politeknik Negeri Lampung Nomor: 066.75/PL.15.8/PP/2019 tanggal April 2019.

\section{Daftar Pustaka}

Adeniran O. I. dan Fabiyi E. (2012). A Cream Formulation of An Effective Mosquito Repellent: A Topical Product From Lemongrass Oil (Cymbopogon citratus) Stapf. Journal Natural Prododuct Plant Resour, 2 (2).

Dwi Setyaningsih, Anton Apriyantonodan Maya Puspita Sari. (2010). Analisis Sensori untuk Industri Pangan dan Agro. IPB Press.

Dwi Setyaningsih, Erliza Hambali dan Muharamia Nasution. (2010). Aplikasi Minyak Sereh Wangi (Citronella Oil) dan Geraniol dalam Pembuatan Skin Lotion Penolak Nyamuk. Jurnal Teknik Industri Pertanian. Volume 17 (3).

Kementerian Perdagangan RI. (2011). Handbook of Commodity Profile, Indonesian Essential Oil The Scents of Natural Life.

Meilgaard, M.C, Civille GV dan Carr BT. (2007). Sensory Evaluation Techniques. 4th ed, Boca Raton, Florida: CRC Press.

Muhtaridi. (2010). Penelitian Pengembangan Minyak Atsiri Sebagai Aromaterapi dan Potensinya Sebagai Produk Sediaan Farmasi. Jurnal Teknik Industri Pertanian. Volume 17 (3).

Peraturan Kepala BPOM Nomor 12 tahun 2014 tentang Persyaratan Mutu Obat Tradisional.

Raditya Iswandana dan Lidya KM Sihombing. (2017). Formulasi Uji Stabilitas Fisik dan Uji Aktifitas Secara In Vitro Sediaan Spray Anti Bau Kaki Yang Mengandung Ekstrak Etanol Daun Sirih (Piper Betle L),Pharmacy Science Resource. ISSN 12407-2354. Volume 4(3).

Rusmini, Dwinita Agustini, Riama Rita Manulang dan Daryono. (2019). Tingkat Kesukaan Konsumen Terhadap Serat Kenat Organik Dengan Pewarnaan 
Alami.Jurnal Penelitian Pertanian

Terapan. Volume 19(1): 58-65.

R.V. Gheetha. (2014). Essential Oil RepellentsA short Review. International Journal Drug Development \& Resource. 6 (2): 20 27.

Serumpun Asa Sereh Wangi, https://ptpnix.co.id, posting 8 November 2018 diunduh 31 Januari, 2019.

Setiawan, Gusmaini dan Hera Nurhayati. (2018). Respons Tanaman Serai Wangi Terhadap Pemupukan NPKMg Pada Tanah Latosol, Buletin Penelitian Tanaman Rempah dan Obat, Vol. 29 No. 2.

Sutiah, K Sofjan Firdausi dan Wahyu Setia Budi. (2008). Studi Kualitas Minyak Goreng Parameter Viskositas da Indeks Bias. Berkala Fisika.Volume 11 (2).

Vivek Chauhan, Anu Kaushik dan Dr. Sudha. (2016). Formulation and Evaluation of Herbal Pain Relief Oil, European Journal of Pharmaceutical and Medical Research, $3(4)$.

W T Eden, D Alighiri, E Cahyono, K I Supardi dan N Wijayati. (2018).Fractionation of Java Citronella Oil and Citronellal Purification by Batch Vacuum Fractional Distillation. IOP Conf. Series: Materials Science and Engineering.

Wa Ode Cakra Nirwana, Chandrawati Cahyani dan Vivi Nurhadianty.(2016). Kajian Daya Proteksi Produk Repelan Nyamuk Demam Berdarah Dengue dalam Bentuk Lotion Berbasis Minyak Atsiri Lokal (Minyak Sereh Wangi dan Minyak Nilam). Jurnal Teknik Kimia. Vol 11.No.1. 